The session "Disharmony in the Juste Milieu: Labor in the July Monarchy" examined aspects of working-class history in the first half of the nineteenth century. Charles Crouch assessed the growing distance between the petit bourgeoisie and the working class in "The Politics of Economic Transformation: Small-Scale Employers, Their Employees and the Demise of Sociability." In addition to structural transformations of the economy, Crouch argued that an increase in popular violence that included calls for a redistribution of wealth alienated the lower middle class from its allies among laboring men. The Revolution of 1848 completed the breach and thus frustrated a common politics. Judith DeGroat's paper, "Gender in the Archives: An Assessment of the Sources for a History of Women's Work in July Monarchy Paris," called for a more complex view of female labor in this period. Focusing on the manufacturing trades, DeGroat asserted that archival sources challenge the contemporary perception of female labor as solely needlework and offer a means to assess women's view of their labor beyond that provided by the printed works of socialist feminists. In "A Repertoire of Contention: Paris' Place de Grève, 1830-1846," Casey Harison explored the collective action of migrant masons. Drawing on Charles Tilly's formulation, Harison suggested that police and the people developed a repertoire of contention-recognized by both groups-that accounts for the revolutionary activity in nineteenth-century Paris.

\title{
Eighty-Eighth Annual Meeting of the
}

\author{
Organization of American Historians
}

\author{
Jennifer Klein \\ University of Virginia \\ David Brundage \\ University of California-Santa Cruz \\ Cecilia Elizabeth O'Leary \\ American University
}

Political historians and labor historians alike were engaged in attempts to redefine their disciplines at the 1995 Organization of American Historians conference, which was held in Washington, D.C., from March 30 to April 2. The search for a "new synthesis" in each of these fields was a feature of panels working to "revitalize political history" and rethink industrial unionism. Some panels, unfortunately, mistook synthesis for bringing in 
everything including the kitchen sink, while others did no more than reinforce parochialism and fragmentation.

Other panels did, however, show that there are new issues and questions emerging in these fields. In "The Production and Reproduction of Subjects," Christopher Tomlins and Elizabeth Faue sought to create a new theoretical foundation for integrating recent work on gender and family into a holistic story of American workers. Echoing his recent book, Tomlins charged that the standard liberal story that posits workers' historical journey from feudal subordination to individual independence is as much a fable as the free market. Focusing on the Early Republic period, he suggested that in order to uncover the relations of authorized power we must look beyond the laws of property to the laws of the positive authority to discipline. The laws of domestic relations (husband/wife, parent/child, master/slave) set up the most basic rules of authorized power. Instead of being undermined by the disengagement of the economy from feudal restrictions, the laws of household relations transmitted the unfreedoms of the household to the marketplace and market relations.

Like Tomlins, Elizabeth Faue argued that social reproduction, rather than production, should be at the center of a new synthetic labor history. According to Faue, both the old and new labor history share the assumption that social identity is shaped by work and the workplace. This productivist model, as she calls it, privileges the male role in production and reproduction and declares their story to be normative. Faue countered this approach by asserting that individuals first experience class as nonworkers. Families and communities are incubators of class identity. Thus we need to gain a fuller understanding of the ways in which communities and households seek to reproduce, or improve, the conditions of their existence.

Nancy Isenberg and William Forbath, the two commentators, were unconvinced. Isenberg criticized Tomlins for failing to analyze the various factors that affected gender relations in the household or women's role in both the household and market. She claimed that his dichotomy of markets and households was unrealistic, for while liberalism did not "uncontain" the economy, it did penetrate and shape household relations. Similarly, Isenberg felt that Faue had not fully addressed issues of power, individual resistance, and the dynamic interaction between markets, law, economy, and household. She claimed that Faue had yet to articulate a precise theory of the transmission of class identity. Ultimately, Isenberg concluded that it is not enough simply to shift the picture from the site of production to that of reproduction. Rather, both historians still needed to explain the connections between production and reproduction.

William Forbath, echoing Isenberg, sought agency and resistance in this historical picture. Forbath, responding primarily to Tomlins' paper, proudly defended the "whiggish" line, claiming that it is certainly "more right than wrong." He insisted that if we look again at the story of collective action at work, historians will find that neither the language nor the authority of master-servant theory fully penetrated the workplace. 
In a panel titled "At the Intersection of Class and Race: Organized Labor, the Left, and the Struggle for Black Equality, 1945-1965," participants discussed issues emerging from three case studies. Alex Lichtenstein examined race relations in Miami's Local 500 of the Transport Workers Union, the largest $\mathrm{CIO}$ local in Florida, and a target of anticommunist purges in the late 1940s. Rejecting the view that communist unionists always gave idealistic support to the struggle for black equality, Lichtenstein demonstrated that in this case both communists and anticommunists approached racial questions "opportunistically" rather than on the basis of principle, and that eventually both sides abandoned the cause of AfricanAmerican workers in the union. Bruce Nelson examined black and white steelworkers at the Atlantic Steel Company in Atlanta, a case characterized by both black civil rights activism and white backlash. Nelson showed that while the international leaders of the United Steelworkers of America voiced a formal commitment to racial justice, they were reluctant to confront the local union's white majority, fearing that efforts to implement racial equality in the workplace would endanger the union itself. Rick Halpern's examination of Louisiana sugar workers, members of the United Packinghouse Workers of America, also stressed the crucial role of white rank-and-file racism but demonstrated that when progressive international leaders linked up with black union activists at the local level, effective antidiscrimination measures could be introduced in the workplace. Over all, the session, which included insightful comments from Gail O'Brien and Oliver Montgomery, a long-time black activist in the United Steelworkers of America, highlighted the importance of working-class racism in the Congress of Industrial Workers and challenged the view that rank-and-file activism was necessarily a progressive phenomenon.

Participants on the panel "Transnational Political Ideologies in Immigrant Communities" addressed the connections between immigrant workers and their homelands. The concept "transnational," in this context, refers to the back-and-forth movement of peoples, cultures, and political strategies, and also to the impact of global developments on immigrant groups. David Brundage, in his paper "Class, Ethnicity, and Radicalism in the Irish Diaspora: The Irish Progressive League, 1917-1920," focused on the shifting alliance between working-class radicalism, conservatism, and Irish national identity. Brundage argued that by World War One, the mainstream Irish nationalist movement in the United States refused to "dilute pure nationalism with any kind of social program." When Irish nationalism emerged as a mass movement between 1916 and 1923, only the very small Irish Progressive League, led mainly by women, kept the tradition of American Land League radicalism alive. While Brundage explored the role of contestation, the need to delve further into the mainstream movement's use of ethnicity to forge a conservative agenda remained on the agenda.

Michael Miller Topp's “Transnationalism and Its Implications for American Immigrant History: The Italian-American Syndicalist Move- 
ment" explored the dynamic but ultimately problematic attempt by immigrants to apply Italian organizing strategies and tactics to American labor struggles. During the Lawrence strike of 1912, the "children's exodus"-a practice long in use in labor disputes in Italy-dramatically demonstrated the potential of importing and adapting organizing techniques from abroad. However, Italian syndicalism failed to have a significant impact on American labor organizing in the long run. Topp explored the positive aspects of the interaction between the two labor movements, but his paper suggested that incorporating the language, symbols, and tactics of the old country can also backfire.

Workers and the Environment:

Pacific Northwest Labor History Association

\author{
Nils Sonntag \\ University of Cincinnati
}

The 1995 conference of the Pacific Northwest Labor History Association (held at the University of Oregon, May 19-21) took as its theme the relationship between workers and the environment. Panels addressed a variety of issues on this subject, including the history of labor-environment relations in British Columbia, labor's environmental organizing strategies, and case studies investigating the complex connections between work and environment.

Keynote speaker John Foster, of the University of Oregon, examined the historical relationship between class and the environment. He analyzed how class issues were connected to or separated from ecological concerns in order to serve perceived class interests. Of special value was his discussion of the conflict between labor and environmentalism in the 1970s and 1980 s, which he traced back to underlying struggles between the working and middle classes. Another keynote speaker, William Robbins of Oregon State University, examined the changing relationship between humans and nature under what he calls the "dominant culture of capitalism." He discussed how this culture has changed the landscape and ecology since the beginnings of industrialization in the western United States.

One panel provided exemplary investigations of labor-environmental relations in British Columbia. Lesley Cooper described workers' strategies for reacting to unemployment during the gold rush of the 1930s, while Mark Leier discussed how Vancouver's early labor movement opposed the creation of parks. Thomas Baker examined how the competition for em- 